\title{
Key Organic Acids in Indigenous Plants in Thailand
}

\section{Benyathip Sukontaprapun, Somsri Charoenkiatkul, Parunya Thiyajai, Monruedee Sukprasansap, Preecha Saetang, Kunchit Judprasong*}

Institute of Nutrition, Mahidol University, Salaya, Phutthamonthon, Nakhon Pathom, Thailand

Email: ${ }^{*}$ kunchit.jud@mahidol.ac.th

How to cite this paper: Sukontaprapun, B., Charoenkiatkul, S., Thiyajai, P., Sukprasansap, M., Saetang, P. and Judprasong, K. (2019) Key Organic Acids in Indigenous Plants in Thailand. American Journal of Plant Sciences, 10, 1855-1870.

https://doi.org/10.4236/ajps.2019.1010131

Received: September 10, 2019

Accepted: October 22, 2019

Published: October 25, 2019

Copyright $\odot 2019$ by author(s) and Scientific Research Publishing Inc. This work is licensed under the Creative Commons Attribution International License (CC BY 4.0).

http://creativecommons.org/licenses/by/4.0/

\begin{abstract}
Organic acids had various health benefits such as citric acid can inhibit stone formation and break up beginning of small kidney stone. On the other hand, some organic acid showed negative health effects such as oxalic acid acts as anti-nutrients and can cause kidney stone. Most of Thai indigenous plants had sour taste; however general people believed that sour taste of plants could contain high ascorbic acid. In addition, there is limit report of organic acids and ascorbic acid in Thai indigenous plants. This study determined organic acids, ascorbic acid, $\mathrm{pH}$, and total acidity in indigenous plants. Forty samples of 29 types of indigenous plants were analyzed. Results showed that young leaves of Cratoxylum formosum found the highest succinic acid (2454 \pm 91 $\mathrm{mg} / 100 \mathrm{~g}$ fresh weight, FW) and high ascorbic acid (142 $\pm 35 \mathrm{mg} / 100 \mathrm{~g} \mathrm{FW})$. Fruits of Antidesma ghaesembilla had high citric acid levels (5161 \pm 109 $\mathrm{mg} / 100 \mathrm{~g} \mathrm{FW})$ but contained very low ascorbic acid (2 mg/100g FW). The sum of organic acids had significant and inverse correlations with $\mathrm{pH}(r=$ $-0.680)$ and positive with total acidity $(r=0.672)$ but was not significantly correlated for ascorbic acid $(r=0.536)$. The sour taste of plants could derive from the sum of organic, citric, and formic acids, but not other organic and ascorbic acids. Against traditional belief, plants having a strong sour taste may not contain significantly high amounts of ascorbic acid.
\end{abstract}

\section{Keywords}

Indigenous Plants, Organic Acids, Ascorbic Acid, Total Acidity

\section{Introduction}

Organic acids are primary metabolites that contribute to plant growth. They are found in large amounts in the metabolic pathways of all plants, especially in 
fruits and vegetables [1] [2], where they influence sensory properties, such as giving sour or tart flavors. Some organic acids can indicate ripeness [3] [4]. Most Thai indigenous plants have a sour taste but it is not clearly known which substances cause this attribute. Vitamin $\mathrm{C}$ or ascorbic acid is believed to play a major role in creating a sour taste. However, this may be not true; for instance, the sour taste of Ma-mao fruits (Antidesma ghaesembilla Gaertn.) does not contain vitamin $\mathrm{C}$. The sour taste may come from other substances, such as oxalic and citric acids [5].

Some organic acids have beneficial health effects; for instance, citric acid can inhibit kidney stone formation [6] [7]. Seltzer et al. [8] and Kang et al. [9] reported that $5.9 \mathrm{mg}$ of citric acid significantly increases secretion of citrate in urine in kidney stone patients. Furthermore, malic acid can stimulate production of saliva in patients suffering from xerostomia symptoms [10] and succinic acid can improve postischemic cardiac function [11]. Alternatively, some types of organic acid are reported to negatively affect health. For instance, oxalic acid can form with the cation mineral to bring about kidney stones [12], while formic acid can cause acidosis [13]. Organic acids can also improve mineral absorption [14]. Greenfield \& Southgate [15] stated that since organic acids provide 3 $\mathrm{kcal} / \mathrm{g}$, it should be included in energy calculations, if any, apart from protein, fat, and carbohydrate (4, 9 and $4 \mathrm{kcal} / \mathrm{g}$, respectively).

To date, limited information exists on organic acids in indigenously consumed plant foods in Thailand and Asian countries where such plants are also eaten. Hence, this study's main purpose is to determine each organic and ascorbic acid, $\mathrm{pH}$, and total acidity in Thai indigenous plants, especially since several such plants are now being commercially grown and can be found in markets, such as Ma-kham-pom (Phyllanthus emblica L.), Ma-kok-pa (Spondias pinnata [L.f.] Kurz), Ma-mao (Antidesma velutinosum Blume), and Pak-wan-pa (Melientha suavis Pierre). In addition, another aim is to evaluate the correlation of selected substances which contribute to the sour taste of plants.

\section{Materials and Methods}

\subsection{Samples}

In total, 40 samples (fresh and/or boiled depending commonly consumed method of each plant) of 29 indigenous plants were collected three times from two conservation areas in Kanchanaburi province (representative of the western region) and Amnatchareon province (representative of the northeastern region) of Thailand. They were identified and collected with only the edible part being selected for analysis. Each edible plant part was prepared for consumption using local preparation methods, i.e., fresh, blanching, boiling. The samples were categorized into six groups based upon the plant part that is commonly consumed, namely, young leaves, flower, fruit, pod, tuber, and young stem (Table 1). The samples were transported under cooled conditions in an ice-box and sent to the analytical ISO 17025 laboratory at the Institute of Nutrition, Mahidol University 
(INMU). Due to growing conditions, the number of samples for each plant over the four-year survey and collection period (2013-2015 and 2019) was limited. However, each sample was analyzed in triplicate.

Table 1. List of local name, scientific name, and edible parts of collected samples.

\begin{tabular}{|c|c|c|}
\hline Local name & Scientific name & Edible (analyzed) parts \\
\hline Book & Amorphophallus sp. & Young stem \\
\hline Cha-aim-tao & Myriopteron extensum & Fruits \\
\hline E-noon & Adenia viridiflora Craib & Young leaves \\
\hline Gac fruit, young & Momordica cochinchinensis Spreng & Young fruits \\
\hline Kae-hang-kang & Markhamia stipulate Seem. var. kerrii Sprague & Flowers \\
\hline Ka-min-pa & Curcuma parviflora Wall. & Tubers \\
\hline Kra-chai-pa & Boesenbergia rotuna & Tubers \\
\hline Kra-chai-pran & Zingiber citriodorum J.Mood \& T. Theleide & Tubers, Young stem \\
\hline Kra-dom & Gymnopetalum chinense & Fruits \\
\hline Kra-don & Careya sphaerica Roxb. & Young leaves, Flowers \\
\hline Kra-pee-jan & Millettia brandisiana Kurz & Young leaves \\
\hline Krua-sai-tan & Aganosma marginata (Roxb.) G. Don & Young leaves (boil and fresh) \\
\hline Ma-due-plong & Ficus hispida L. f. & Fruits \\
\hline Ma-kham-pom & Phyllanthus emblica L. & Fruits \\
\hline Ma-kok-pa & Spondias pinnata (L.f.) Kurz & Fruits \\
\hline Ma-mao & Antidesma velutinosum Blume & Fruits (ripe, fresh) \\
\hline Ma-ra-pa & Momordica charantia & Young leaves \\
\hline Pak-kood & Diplazium esculentum (Retz.) Swartz & Young leaves (blanch, fresh) \\
\hline Pak-wan-pa & Melientha suavis Pierre & Young leaves, Flowers, Fruits \\
\hline Pe-ka & Oroxylum indicum (L.) Kurz & Pod \\
\hline San-yai & Dillenia sp. & Fruits \\
\hline Som-lom & Aganonerion polymorphum Pierre ex Spire & Young leaves \\
\hline Som-mong & Garcinia cowa Roxb.ex DC. & Young leaves (blanch, fresh) \\
\hline Song-fa & $\begin{array}{l}\text { Clausena wallichii Oliv. var. guillauminii } \\
\text { (Tanaka) J.P.Molino }\end{array}$ & Young leaves \\
\hline Ta-kuek & Albizia lebbeck (L.) Benth & Young leaves \\
\hline Teaw-deang & $\begin{array}{l}\text { Cratoxylum formosum subsp. Pruniflorum } \\
\text { (Kurz) Gogel. }\end{array}$ & Young leaves \\
\hline Teaw-kaw & Cratoxylum formosum (Jack) Dyer & Young leaves \\
\hline Teaw-mon & Cratoxylum cochinchinense (Lour.) Blume & Young leaves \\
\hline Wan-pro & Kaempferia galanga L. & Leaves (young, mature) \\
\hline
\end{tabular}




\subsection{Sample Preparation}

Each indigenous plant sample was cleaned twice with tap water and once with deionized water. In each source of sample, the edible part of each sample was collected, weighed, and divided into two portions. The first portion was prepared as a homogeneous sample for moisture analysis only. The other portion entailed cooked samples that were blanched or boiled depending on the commonly used preparation method. Thereafter, both raw and cooked samples were homogenized using a food processor (Mara ${ }^{\circ}$, Thailand) and dried using a freeze-dried system (Heto ${ }^{\circ}$, Power Dry PL9000 Freeze Dryer, Thermo Fisher Scientific). They were then weighed, ground, vacuum-packed in laminated aluminum foil bags, and stored at $20^{\circ} \mathrm{C}$ until analysis.

\subsection{Moisture Content Determination}

Moisture content was analyzed by drying according to the Official Analytical Chemists, Method 927.05 [16] [17]. The homogenized sample was weighed into an aluminum container and dried in a hot air oven at $100^{\circ} \mathrm{C} \pm 1^{\circ} \mathrm{C}$ until constant weight. The results were expressed as gram per $100 \mathrm{~g}$ of fresh weight (FW).

\subsection{Organic Acid Determination (Oxalic Acid, Citric Acid, Malic Acid, Succinic Acid, Formic Acid, Acetic Acid)}

Organic acids were extracted from $1 \mathrm{~g}$ of finely ground-dried sample with $50 \mathrm{~mL}$ $2 \mathrm{M} \mathrm{HCl}$ at temperature $80^{\circ} \mathrm{C}$ for 15 minutes. They were centrifuged at $3000 \mathrm{rpm}$ for 15 minutes. Supernatant was passed through a filter of $0.45 \mu \mathrm{m}$ cellulose acetate membrane. Organic acid contents were determined by the HPLC method. A $20 \mu \mathrm{L}$ of filtrated sample was injected into the HPLC system (Waters chromatography system, Milford, USA) with UV detector (Waters ${ }^{\circledR} 486$ ), set at $210 \mathrm{~nm}$. The separation of each organic acid was carried out on a $300 \times 7.8 \mathrm{~mm}$ Biorad Aminex ion exclusion column (HPX-87H), using an isocratic elution at 0.5 $\mathrm{mL} / \mathrm{min}$ with $0.0125 \mathrm{M}$ sulphuric acid as a mobile phase. Figure 1 shows a chromatogram corresponding to a six-component mixture of standards and an indigenous sample. One can observe the good resolution and separation of the identified organic acids in a real sample. All samples were analyzed in triplicate. Organic acid contents were calculated against their standard curves (calibration of mix cocktail standards) [18] [19].

\subsection{Ascorbic Acid Determination}

Ascorbic acid or vitamin C was determined using the HPLC method [20]. In brief, each sample was extracted in 3\% metaphosphoric acid and the homogenate was filtered. Ascorbic acid was separated by reversed-phase HPLC with UV detection at $248 \mathrm{~nm}$ (Agilent ${ }^{\oplus} 1100$ series, USA) and quantified against external standards.

\subsection{Total Acidity and $\mathrm{pH}$ Determination}

Total acidity and $\mathrm{pH}$ were determined by the potentiometric method using a 


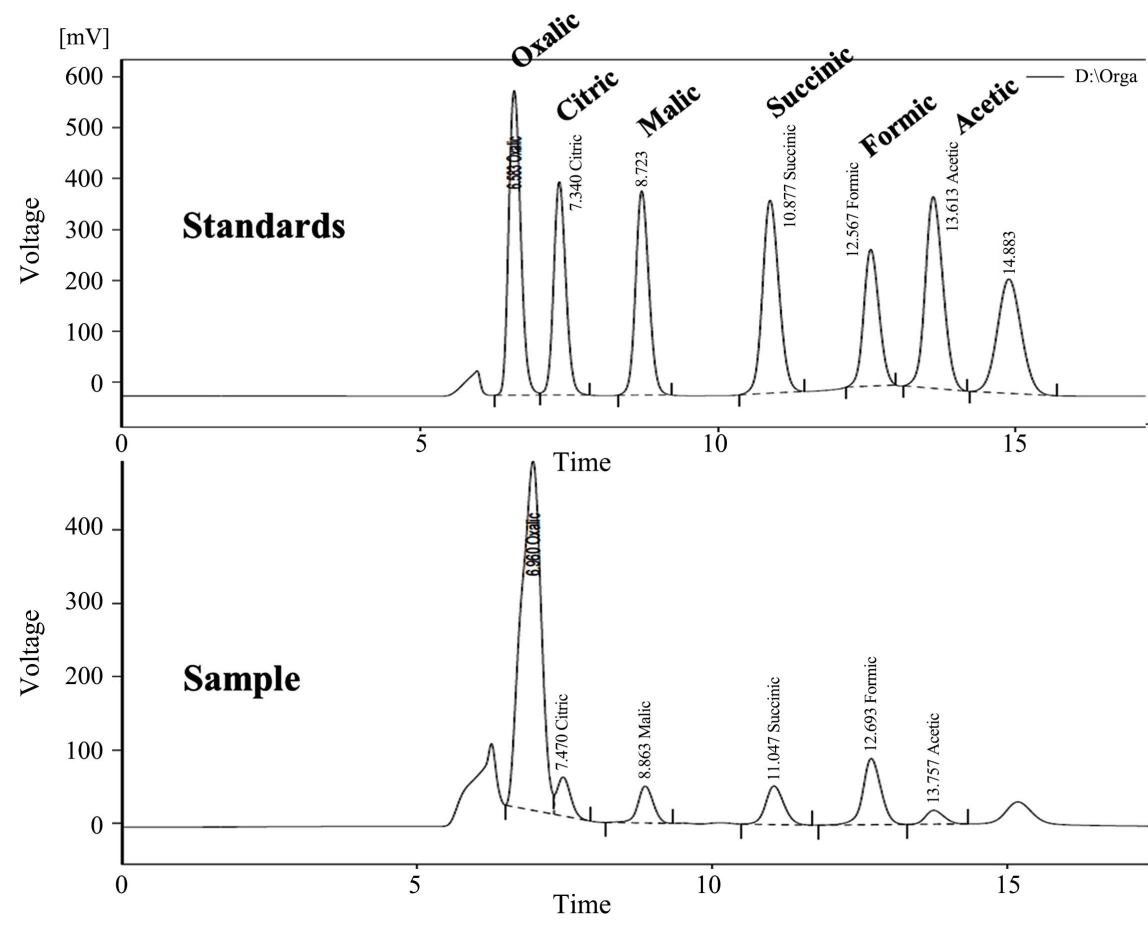

Figure 1. Chromatogram of standards and Cha-moung leaves (quality control sample, an representative of sample).

glass electrode according to the AOAC Method 942.15B [16] [17]. Each sample was dissolved with deionized water, stirred, measured for $\mathrm{pH}$ value, and then titrated to the range of $\mathrm{pH} 8.10 \pm 0.2$. Total acidity was calculated, as percentage, based on each type of dominant organic acid in the sample.

\subsection{Quality Control System}

For precision in the organic acid analysis, Cha-moung leaves were dried at $50^{\circ} \mathrm{C}$ $\pm 1^{\circ} \mathrm{C}$ until dryness then ground into fine particles. They were then used as in-house quality control (QC) samples for representative organic acids, since these leaves are known to contain a significant amount of oxalic acid and several other organic acids. The assigned values of oxalic were developed from duplicate analysis of 10 single samples of the in-house QC samples on 10 different days. The QC sample was then analyzed along with the unknown samples in each run of the organic acid measurement over time. Due to a lack of an available certified reference material, spike standard organic acids in a QC sample were performed $(\mathrm{n}=10)$ to demonstrate accuracy. Limit of detection (LOD) and limit of quantitation (LOQ) were studied using spiked lowest concentration of mixed standard into the QC sample and then calculated as 3 and 10 times of standard deviation from 10 times analysis, respectively.

\section{Result and Discussion}

\subsection{Quality Control System}

The Cha-moung (Garcinia cowa Roxb.) dried leaf, as the in-house QC sample, 
contained a high amount of oxalic acid $(1120 \pm 103 \mathrm{mg} / 100 \mathrm{~g}$ of fresh weight, FW). The organic acid content in each analytical set stayed within the acceptable range (mean \pm 2 standard deviation of the assigned value). Recoveries of oxalic acid added (10 $\mathrm{mg} / \mathrm{g}$ of sample) prior to sample extraction were performed in both the in-house QC sample and the dried food samples. Percentages of recovery of oxalic acids ranged from $90.6 \%$ to $99.4 \%$ (Table 2) which stayed in the acceptable recovery range $(90 \%-107 \%)$ [17]. LOD of oxalic, citric, malic, succinic, formic, and acetic acids were 0.9, 2.2, 2.0, 0.2, 0.1, and $3.0 \mathrm{mg} / 100 \mathrm{~g}$, respectively. LOQ of oxalic, citric, malic, succinic, formic, and acetic acids were $3.0,7.3,12.0,0.5,0.5$, and $9.0 \mathrm{mg} / 100 \mathrm{~g}$ respectively.

\subsection{Moisture and Organic Acids}

The major component in the studied plants was water, ranging from $69.9 \mathrm{~g} / 100 \mathrm{~g}$ to $97.4 \mathrm{~g} / 100 \mathrm{~g}$ FW (Tables 3-6). In general, organic acids can be divided into two groups. The first group entails organic acids that have been reported to have negative health effects, such as oxalic acid. The second group comprises those that provide health benefits, such as citric, malic, succinic, and acetic acids. Results and discussion for each organic acid are presented in Tables 3-6.

Table 2. Percent recovery, LOD, and LOQ of each organic acid $(\mathrm{n}=10)$.

\begin{tabular}{cccc}
\hline Organic acids & \% Recovery $($ Mean \pm SD) & LOD $(\mathrm{mg} / 100 \mathrm{~g})$ & LOQ $(\mathrm{mg} / 100 \mathrm{~g})$ \\
\hline Oxalic acid & $90.6 \pm 11.5$ & 0.9 & 3 \\
Citric acid & $91.8 \pm 9.7$ & 2.2 & 7.3 \\
Malic acid & $97.8 \pm 5.4$ & 2 & 12 \\
Succinic acid & $98.1 \pm 7.3$ & 0.2 & 0.5 \\
Formic acid & $95.1 \pm 2.3$ & 0.1 & 0.5 \\
Acetic acid & $99.4 \pm 3.5$ & 3 & 9 \\
\hline
\end{tabular}

Table 3. Organic acids and other studied contents of young leaves consumed indigenous plants (per $100 \mathrm{~g}$ edible fresh weight, $\mathrm{FW})^{1}$.

\begin{tabular}{|c|c|c|c|c|c|c|c|c|c|c|c|}
\hline \multirow{2}{*}{ Samples } & \multirow{2}{*}{$\begin{array}{l}\text { Moisture } \\
\text { (g) }\end{array}$} & \multicolumn{7}{|c|}{ Organic acids (mg) } & \multirow{2}{*}{$\begin{array}{c}\text { Ascorbic } \\
(\mathrm{mg})\end{array}$} & \multirow{2}{*}{$\mathrm{pH}$} & \multirow{2}{*}{$\begin{array}{c}\text { Total } \\
\text { acidity } \\
(\%)\end{array}$} \\
\hline & & Oxalic & Citric & Malic & Succinic & Formic & Acetic & Sum & & & \\
\hline \multicolumn{12}{|c|}{ Young leaves consumed plants: } \\
\hline $\begin{array}{c}\text { E-noon, boiled young } \\
\text { leaves }\end{array}$ & $89.7 \pm 0.3$ & $70 \pm 1$ & $79 \pm 6$ & $571 \pm 7$ & $1 \pm 0$ & $29 \pm 4$ & $299 \pm 1$ & $1050 \pm 2$ & $73 \pm 33$ & $6.64 \pm 0.06$ & $0.91 \pm 0.05$ \\
\hline $\begin{array}{c}\text { Kra-don, fresh young } \\
\text { leaves }\end{array}$ & $85.3 \pm 0.2$ & $258 \pm 16$ & $153 \pm 36$ & $1381 \pm 986$ & $220 \pm 4$ & $30 \pm 9$ & $288 \pm 84$ & $2330 \pm 916$ & $8 \pm 1$ & $7.09 \pm 0.05$ & $2.50 \pm 0.06$ \\
\hline $\begin{array}{l}\text { Kra-pee-jan, fresh } \\
\text { young leaves }\end{array}$ & $82.4 \pm 0.4$ & $43 \pm 1$ & $\mathrm{ND}^{2}$ & ND & $528 \pm 36$ & ND & $182 \pm 128$ & $699 \pm 147$ & $18 \pm 5$ & $7.04 \pm 0.39$ & $1.29 \pm 0.13$ \\
\hline $\begin{array}{l}\text { Krua-sai-tan, boiled } \\
\text { young leaves }\end{array}$ & $83.8 \pm 0.3$ & $80 \pm 1$ & ND & ND & ND & ND & $463 \pm 153$ & $543 \pm 154$ & $29 \pm 5$ & $6.22 \pm 0.10$ & $0.82 \pm 0.04$ \\
\hline $\begin{array}{c}\text { Krua-sai-tan, fresh } \\
\text { young leaves }\end{array}$ & $75.4 \pm 0.6$ & $84 \pm 1$ & ND & ND & ND & ND & $329 \pm 103$ & $413 \pm 103$ & $10 \pm 6$ & $6.20 \pm 0.09$ & $0.79 \pm 0.05$ \\
\hline $\begin{array}{l}\text { Ma-ra-pa, blanched } \\
\text { young leaves }\end{array}$ & $85.3 \pm 0.2$ & $104 \pm 2$ & $123 \pm 1$ & ND & $509 \pm 2$ & ND & ND & $736 \pm 2$ & $5 \pm 1$ & $6.24 \pm 0.20$ & $0.87 \pm 0.10$ \\
\hline
\end{tabular}




\section{Continued}

\begin{tabular}{|c|c|c|c|c|c|c|c|c|c|c|}
\hline $\begin{array}{c}\text { Pak-kood, blanched } \\
\text { young leaves }\end{array}$ & $92.8 \pm 0.3$ & $34 \pm 3$ & $\mathrm{ND}$ & $148 \pm 5$ & $678 \pm 13$ & $\mathrm{ND}$ & $\mathrm{ND}$ & $860 \pm 20$ & $5 \pm 3$ & $6.52 \pm 0.07 \quad 1.16 \pm 0.07$ \\
\hline $\begin{array}{c}\text { Pak-kood, fresh young } \\
\text { leaves }\end{array}$ & $93.2 \pm 0.2$ & $48 \pm 2$ & $\mathrm{ND}$ & $112 \pm 3$ & $216 \pm 99$ & $\mathrm{ND}$ & $\mathrm{ND}$ & $376 \pm 199$ & $3 \pm 1$ & $7.30 \pm 0.250 .45 \pm 0.09$ \\
\hline $\begin{array}{c}\text { Pak-wan-pa, blanched } \\
\text { young leaves }\end{array}$ & $75.4 \pm 0.6$ & $20 \pm 1$ & $66 \pm 3$ & $291 \pm 4$ & $9 \pm 1$ & $41 \pm 4$ & $22 \pm 6$ & $450 \pm 5$ & $68 \pm 26$ & $6.21 \pm 0.12 \quad 0.80 \pm 0.06$ \\
\hline $\begin{array}{c}\text { Som-lom, fresh young } \\
\text { leaves }\end{array}$ & $80.4 \pm 0.5$ & $85 \pm 8$ & $\mathrm{ND}$ & $168 \pm 4$ & $7 \pm 2$ & $40 \pm 2$ & $121 \pm 16$ & $421 \pm 1$ & $329 \pm 58$ & $6.20 \pm 0.090 .79 \pm 0.10$ \\
\hline $\begin{array}{c}\text { Som-mong, fresh young } \\
\text { leaves }\end{array}$ & $85.9 \pm 0.3$ & $656 \pm 10$ & $\mathrm{ND}$ & ND & $1151 \pm 49$ & ND & $470 \pm 73$ & $2277 \pm 22$ & $356 \pm 78$ & $3.81 \pm 0.1016 .27 \pm 0.03$ \\
\hline $\begin{array}{c}\text { Som-mong, blanched } \\
\text { young leaves }\end{array}$ & $84.4 \pm 0.4$ & $153 \pm 8$ & $85 \pm 1$ & $112 \pm 16$ & $18 \pm 2$ & $102 \pm 14$ & $153 \pm 4$ & $622 \pm 31$ & $340 \pm 59$ & $3.80 \pm 0.1216 .07 \pm 0.10$ \\
\hline
\end{tabular}

${ }^{1}$ Three individual samples were analyzed in duplicate and presented as mean + standard deviation; ${ }^{2} \mathrm{ND}=\mathrm{Not}$ detectable (less than LOD).

Table 4. Organic acids and other studied contents of young leaves and flower consumed indigenous plants (per $100 \mathrm{~g}$ FW) ${ }^{1}$.

\begin{tabular}{|c|c|c|c|c|c|c|c|c|c|c|c|}
\hline \multirow{2}{*}{ Samples } & \multirow{2}{*}{$\begin{array}{l}\text { Moisture } \\
\text { (g) }\end{array}$} & \multicolumn{7}{|c|}{ Organic acids (mg) } & \multirow{2}{*}{$\begin{array}{c}\text { Ascorbic } \\
(\mathrm{mg})\end{array}$} & \multirow{2}{*}{$\mathrm{pH}$} & \multirow{2}{*}{$\begin{array}{c}\text { Total } \\
\text { acidity } \\
(\%)\end{array}$} \\
\hline & & Oxalic & Citric & Malic & Succinic & Formic & Acetic & Sum & & & \\
\hline $\begin{array}{c}\text { Song-fa, } \\
\text { fresh young leaves }\end{array}$ & $69.9 \pm 0.6$ & $486 \pm 22$ & $8 \pm 3$ & $48 \pm 3$ & $39 \pm 1$ & $198 \pm 13$ & $449 \pm 35$ & $1229 \pm 122$ & $153 \pm 35$ & $6.36 \pm 0.10$ & $1.09 \pm 0.04$ \\
\hline $\begin{array}{c}\text { Ta-keuk, } \\
\text { fresh young leaves }\end{array}$ & $81.3 \pm 0.3$ & $82 \pm 10$ & $\mathrm{ND}^{2}$ & $225 \pm 32$ & $596 \pm 6$ & $326 \pm 57$ & $\mathrm{ND}$ & $1228 \pm 21$ & $161 \pm 79$ & $6.29 \pm 0.21$ & $1.24 \pm 0.11$ \\
\hline $\begin{array}{c}\text { Teaw-daeng, } \\
\text { fresh young leaves }\end{array}$ & $80.9 \pm 0.2$ & $34 \pm 6$ & ND & $1361 \pm 61$ & $2454 \pm 91$ & ND & $1508 \pm 325$ & $5356 \pm 271$ & $142 \pm 35$ & $5.50 \pm 0.13$ & $6.09 \pm 0.71$ \\
\hline $\begin{array}{c}\text { Teaw-kaw, } \\
\text { fresh young leaves }\end{array}$ & $79.6 \pm 0.4$ & $32 \pm 4$ & $\mathrm{ND}$ & $1083 \pm 12$ & $2330 \pm 101$ & $\mathrm{ND}$ & $20 \pm 5$ & $3465 \pm 19$ & $136 \pm 34$ & $5.24 \pm 0.05$ & $3.67 \pm 0.36$ \\
\hline $\begin{array}{c}\text { Teaw-mon, } \\
\text { fresh young leaves }\end{array}$ & $74.5 \pm 0.5$ & $69 \pm 3$ & $21 \pm 3$ & $124 \pm 29$ & $1689 \pm 145$ & $100 \pm 70$ & $139 \pm 13$ & $2113 \pm 94$ & $102 \pm 36$ & $5.68 \pm 0.02$ & $2.20 \pm 0.19$ \\
\hline $\begin{array}{c}\text { Wan-pro, } \\
\text { fresh young leaves }\end{array}$ & $94.6 \pm 0.2$ & $53 \pm 2$ & $\mathrm{ND}$ & ND & $\mathrm{ND}$ & ND & ND & $53 \pm 2$ & $3 \pm 2$ & $5.88 \pm 0.25$ & $1.05 \pm 0.14$ \\
\hline $\begin{array}{c}\text { Wan-pro, } \\
\text { Fresh mature leaves }\end{array}$ & $94.4 \pm 0.1$ & $611 \pm 288$ & $\mathrm{ND}$ & $25 \pm 15$ & ND & $11 \pm 7$ & $161 \pm 49$ & $808 \pm 333$ & $4 \pm 1$ & $6.22 \pm 0.17$ & $1.81 \pm 0.22$ \\
\hline \multicolumn{12}{|c|}{ Flowers consumed plants: } \\
\hline $\begin{array}{l}\text { Kae-hang-kang, } \\
\text { Fresh flower }\end{array}$ & $75.4 \pm 0.3$ & ND & ND & $85 \pm 25$ & ND & ND & $254 \pm 10$ & $339 \pm 14$ & $2 \pm 1$ & $6.19 \pm 0.05$ & $0.77 \pm 0.08$ \\
\hline $\begin{array}{l}\text { Kra-don, } \\
\text { fresh flower }\end{array}$ & $84.8 \pm 0.7$ & $119 \pm 25$ & ND & $952 \pm 138$ & $1287 \pm 296$ & ND & ND & $4358 \pm 406$ & $3 \pm 1$ & $5.49 \pm 0.30$ & $4.29 \pm 0.31$ \\
\hline $\begin{array}{c}\text { Pak-wan-pa, } \\
\text { blanched flowers }\end{array}$ & $78.4 \pm 0.6$ & $16 \pm 1$ & $207 \pm 11$ & $808 \pm 10$ & $12 \pm 1$ & $57 \pm 2$ & $572 \pm 156$ & $1744 \pm 153$ & $46 \pm 15$ & $6.76 \pm 0.07$ & $1.86 \pm 0.03$ \\
\hline $\begin{array}{l}\text { Pak-wan-pa, } \\
\text { fresh flowers }\end{array}$ & $72.1 \pm 0.5$ & $15 \pm 1$ & $167 \pm 8$ & $777 \pm 16$ & $14 \pm 1$ & $38 \pm 5$ & $859 \pm 73$ & $1823 \pm 41$ & $37 \pm 14$ & $6.69 \pm 0.07$ & $1.73 \pm 0.03$ \\
\hline
\end{tabular}

${ }^{1}$ Three individual samples were analyzed in triplicate and presented as mean \pm standard deviation; ${ }^{2} \mathrm{ND}=$ Not detectable (less than LOD). 
Table 5. Organic acids and other studied contents of fruit consumed indigenous plants (per $100 \mathrm{~g} \mathrm{FW})^{1}$.

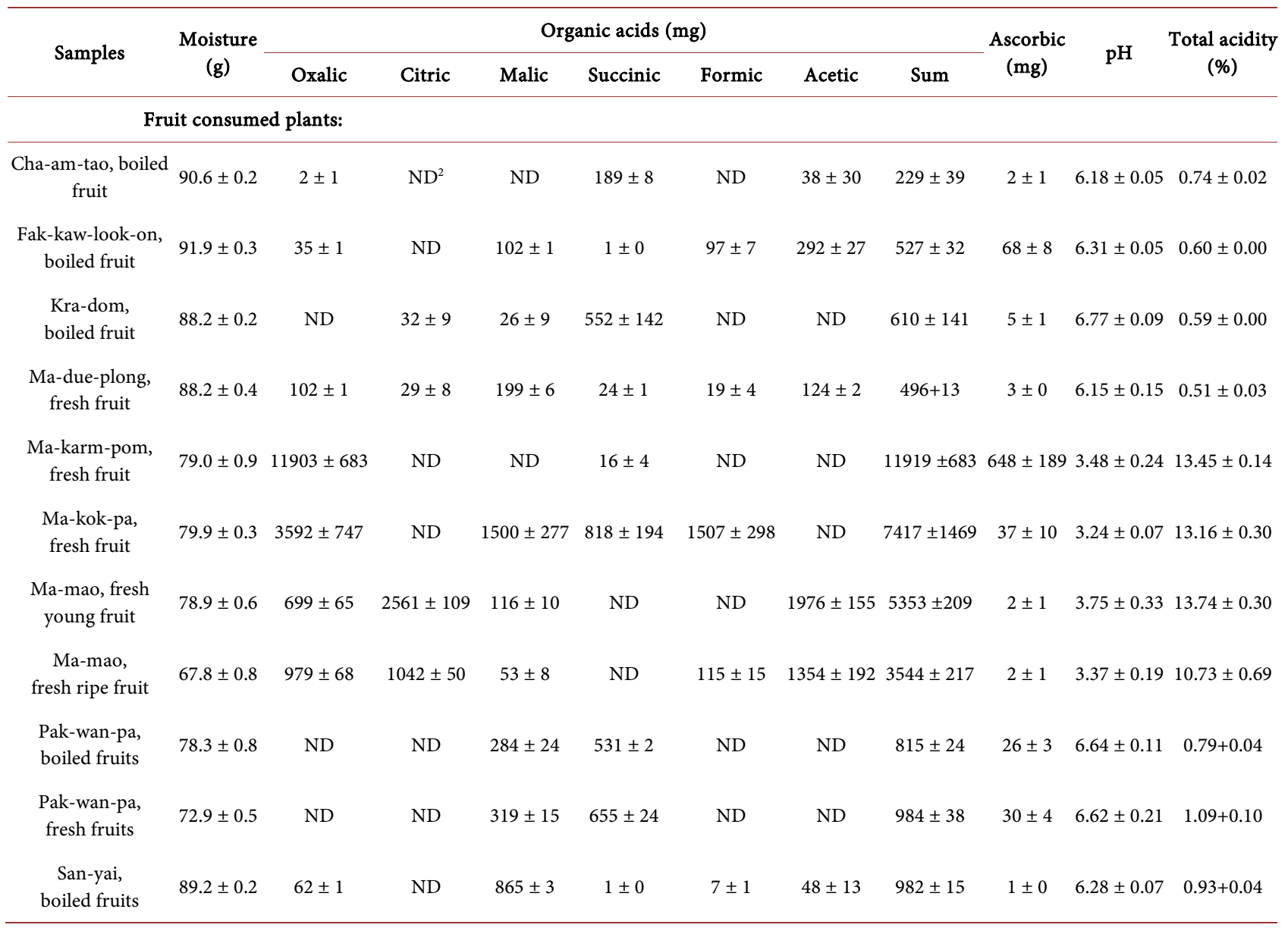

${ }^{1}$ Three individual samples were analyzed in triplicate and presented as mean \pm standard deviation; ${ }^{2} \mathrm{ND}=$ Not detectable (less than LOD).

Table 6. Organic acids and other studied contents of pods, tubers, and young stems consumed indigenous plants (per $100 \mathrm{~g}$ FW) ${ }^{1}$.

\begin{tabular}{|c|c|c|c|c|c|c|c|c|c|c|c|}
\hline \multirow{2}{*}{ Samples } & \multirow{2}{*}{$\begin{array}{c}\text { Moisture } \\
\text { (g) }\end{array}$} & \multicolumn{7}{|c|}{ Organic acids (mg) } & \multirow{2}{*}{$\begin{array}{l}\text { Ascorbic } \\
\text { (mg) }\end{array}$} & \multirow{2}{*}{$\mathrm{pH}$} & \multirow{2}{*}{$\begin{array}{l}\text { Total } \\
\text { acidity } \\
(\%)\end{array}$} \\
\hline & & Oxalic & Citric & Malic & Succinic & Formic & Acetic & Sum & & & \\
\hline \multicolumn{12}{|c|}{ Pods consumed plants: } \\
\hline Pe-ka, fresh pod & $87.1 \pm 0.5$ & $31 \pm 6$ & $\mathrm{ND}^{2}$ & $21 \pm 3$ & $689 \pm 310$ & $102 \pm 12$ & ND & $842 \pm 313$ & $5 \pm 2$ & $5.95 \pm 0.45$ & $1.05 \pm 0.13$ \\
\hline \multicolumn{12}{|c|}{ Tubers consumed plants: } \\
\hline $\begin{array}{l}\text { Ka-min-pa, } \\
\text { fresh tubers }\end{array}$ & $85.3 \pm 0.4$ & $446 \pm 16$ & $133 \pm 24$ & $84 \pm 28$ & $\mathrm{ND}$ & $27 \pm 7$ & $\mathrm{ND}$ & $690 \pm 73$ & $1 \pm 0$ & $6.24 \pm 0.07$ & $0.85 \pm 0.04$ \\
\hline $\begin{array}{l}\text { Ka-chai-pa, } \\
\text { fresh tubers }\end{array}$ & $84.9 \pm 0.6$ & $295 \pm 10$ & $92 \pm 1$ & $3 \pm 2$ & ND & $\mathrm{ND}$ & $\mathrm{ND}$ & $394 \pm 5$ & $1 \pm 0$ & $6.13 \pm 0.12$ & $0.44 \pm 0.03$ \\
\hline $\begin{array}{l}\text { Ka-chai-pran, } \\
\text { boiled tubers }\end{array}$ & $88.6 \pm 0.3$ & $143 \pm 3$ & $159 \pm 12$ & $80 \pm 2$ & ND & $27 \pm 4$ & $24 \pm 5$ & $434 \pm 10$ & $1 \pm 0$ & $6.21 \pm 0.10$ & $0.80 \pm 0.05$ \\
\hline $\begin{array}{c}\text { Book, } \\
\text { boiled young stem }\end{array}$ & $97.4 \pm 0.2$ & $8 \pm 0$ & $\mathrm{ND}$ & $64 \pm 5$ & ND & ND & $\mathrm{ND}$ & $71 \pm 5$ & $1 \pm 0$ & $5.77 \pm 0.14$ & $0.59 \pm 0.14$ \\
\hline $\begin{array}{l}\text { Ka-chai-pran, } \\
\text { boiled young-stem }\end{array}$ & $83.8 \pm 0.5$ & $208 \pm 2$ & ND & $76 \pm 4$ & ND & $35 \pm 6$ & $139 \pm 26$ & $458 \pm 33$ & $1 \pm 0$ & $6.21 \pm 0.08$ & $0.80 \pm 0.08$ \\
\hline
\end{tabular}

${ }^{1}$ Three individual samples were analyzed in triplicate and presented as mean \pm standard deviation; ${ }^{2} \mathrm{ND}=\mathrm{Not}$ detectable $($ less than LOD). 


\subsubsection{Oxalic Acid}

Most indigenous plants in this study contained an oxalic acid content lower than $300 \mathrm{mg} / 100 \mathrm{~g} \mathrm{FW}$, except for some leaves, fruits, and tubers. For leaves, fresh leaves of Som-mong (Garcinia cowa Roxb.ex DC.) and mature leaves of Wan-pro (Kaempferia galanga L) had oxalic acid levels at $656 \pm 10$ and $611 \pm$ $288 \mathrm{mg} / 100 \mathrm{~g}$ FW, respectively. For observed changes after cooking, oxalic acid in blanched young leaves of Som-mong (Garcinia cowa Roxb.ex DC.) (656 \pm 10 $\mathrm{mg} / 100 \mathrm{~g} \mathrm{FW}$ ) showed a dramatic decrease of about 4 times compared to the fresh sample $(153 \pm 8 \mathrm{mg} / 100 \mathrm{~g} \mathrm{FW})$. This finding agrees well with studies by Savage et al. [18], Judprasong et al. [19], and Virginia et al. [21], which reported that cooking in water can lead to the leaching of soluble oxalate into the water thus reducing the oxalate content in foods.

For fruits of consumed plants, fresh Ma-karm-pom (Phyllanthus emblica L.) fruit had the highest oxalic acid content $(11,903 \pm 683 \mathrm{mg} / 100 \mathrm{~g} \mathrm{FW})$, which agrees with $\mathrm{Ha} \mathrm{Vu}$ Hong Nguyen et al. [22] who reported a high oxalate content in this fruit $(7567 \mathrm{mg} / 100 \mathrm{~g}$ FW or $41,577 \mathrm{mg} / 100 \mathrm{~g}$ dry weight, DW). Ma-karmpom (Phyllanthus emblica L.) grown in India, $\mathrm{Ha} \mathrm{Vu}$ Hong Nguyen et al. [22] presented values of oxalic acid content higher than those exhibited in this study. Fresh fruits of Ma-kok-pa (Spondias pinnata (L.f.) Kurz) contained the second level of oxalic acid at $3592 \pm 747 \mathrm{mg} / 100 \mathrm{~g}$ FW. Fresh ripe fruits of Ma-mao ( $A n-$ tidesma velutinosum Blume) had higher oxalic acid content $(979 \pm 68 \mathrm{mg} / 100 \mathrm{~g}$ FW) than fresh young fruits $(699 \pm 65 \mathrm{mg} / 100 \mathrm{~g} \mathrm{FW})$, which agrees with a study by Yoshikawa et al. [23] that noted that oxalic acid increased by age and in overripe plants. For tubers of consumed plants, fresh tubers of Ka-min-pa (Curcuma sp.) and Kra-chai-pa (Boesenbergia rotuna) contained oxalic acid at $446 \pm 16$ and $295 \pm 10 \mathrm{mg} / 100 \mathrm{~g} \mathrm{FW}$, respectively.

\subsubsection{Citric Acid}

Citric acid has both positive and negative health benefits. One positive benefit of citric acid is that it can prevent kidney stone formation and can break up the formation of small kidney stones [6] [7]. Moreover, Seltzer et al. [8] and Kang et al. [9] reported that $5.9 \mathrm{mg}$ of citric acid significantly increases secretion of citrate in urine when it used as a medical therapy in kidney stone patients. Most Thai indigenous plants have citric acid contents lower than $100 \mathrm{mg} / 100 \mathrm{~g} \mathrm{FW}$, except for parts of some leaves, flowers, fruits, and tubers. In general, citric acid gives a sharp, sour taste and is usually found in citrus fruits and some fruit juices. In all of this study's samples, some fruit parts had a great amount of citric acid, whereas other parts had small citric acid content. Fresh young fruits of Ma-mao (Antidesma velutinosum Blume) (green color) had the highest citric acid content $(2561 \pm 109 \mathrm{mg} / 100 \mathrm{~g} \mathrm{FW})$ about two times higher than fresh ripe Ma-mao fruits (red color) $(1042 \pm 50 \mathrm{mg} / 100 \mathrm{~g} \mathrm{FW})$. This finding agrees well with previous reports [24] that noted that unripe fruits had higher citric acid content than ripe fruits in two species of the family Averrhoa bilimbi and star fruits. 
For parts of consumed leaves, Kra-don (Careya sphaerica Roxb) and Ma-ra-pa (Momordica charantia) are the two plants in this group that contained citric acid content higher than $100 \mathrm{mg} / 100 \mathrm{~g}$ FW. For flowers of consumed plants, blanched and fresh flowers of the Pak-wan-pa (Melientha suavis Pierre) contained citric acid levels at $207 \pm 11$ and $167 \pm 8 \mathrm{mg} / 100 \mathrm{~g} \mathrm{FW}$, respectively. For tubers of consumed plants, fresh tubers of Ka-min-pa (Curcuma sp.) and boiled tubers of Kra-chai-pran (Zingiber citriodorum J. Mood and T. Theleide) had citric acid levels at $133 \pm 24$ and $159 \pm 12 \mathrm{mg} / 100 \mathrm{~g} \mathrm{FW}$, respectively.

\subsubsection{Malic Acid}

One benefit of malic acid is that it stimulates the production of saliva that can improve antihypertensive-induced xerostomia [10]. Kra-don (Careya sphaerica Roxb.) had the greatest amount of malic acid, especially in certain parts of leaves and flowers (1381 \pm 986 and $952 \pm 138 \mathrm{mg} / 100 \mathrm{~g} \mathrm{FW}$, respectively). The taste of this leaf and flower is tart, similar to the taste of malic acid [25]. For parts of leaves consumed, fresh young leaves of Tew-deang (Cratoxylum formosum subsp. Pruniflorum [Kurz] Gogel.) and Tew-kaw (Cratoxylum formosum [Jack] Dyer) also contained the highest malic acid content (1361 \pm 61 and $1083 \pm 12$ $\mathrm{mg} / 100 \mathrm{~g}$ FW, respectively) when compared to other studied plants. Fresh flowers of Pak-wan-pa (Melientha suavis Pierre) had a high amount of malic acid (777 $\pm 16 \mathrm{mg} / 100 \mathrm{~g} \mathrm{FW}$, respectively); whereas it had a moderate content in fruits and blanched leaves $(319 \pm 15$ and $291 \pm 4 \mathrm{mg} / 100 \mathrm{~g} \mathrm{FW})$. A study on the effect of minerals in sand cultures on the malic acid content of Valencia orange leaf tissue demonstrated that the high calcium level in sand culture positively influences increasing malic acid content [26].

\subsubsection{Succinic Acid}

No studies have reported on the content of succinic acid in young plant leaves. Succinic acid is assumed not to be a main acid in plants [27]. However, this study found a very high amount of succinic acid in fresh young leaves of Tew-daeng (Cratoxylum formosum subsp. Pruniflorum [Kurz] Gogel.), Tew-kaw (Cratoxylum formosum [Jack] Dyer) and Tew-mon (Cratoxylum cochinchinense [Lour.] Blume) $(2452 \pm 91,2330 \pm 101$, and $1689 \pm 145 \mathrm{mg} / 100 \mathrm{~g} \mathrm{FW}$, respectively). These three plants are in the family of Guttiferae, which generally has a sour taste. Sakamoto et al. [11] reported that one benefit of succinic acid is that its salt improved post ischemic cardiac function, which can guard against ischemia/reperfusion cardiac injury. On the other hand, other parts of plants consumed contained low succinic acid contents.

\subsubsection{Formic Acid}

Formic acid is not a major organic acid in plants. It is mainly founded in coffee [28]. In this study, fresh fruit of Ma-kok-pa (Spondias pinnata (L.f.) Kurz) contained the highest amount of formic acid $(1507 \pm 298 \mathrm{mg} / 100 \mathrm{~g}$ FW). Fresh young leaves of Ta-keuk (Albizia lebbeck (L.) Benth) and Song-fa (Clausena wallichii Oliv. var. guillauminii) had moderate amounts of formic acid (326 \pm 57 
and $198 \pm 13 \mathrm{mg} / 100 \mathrm{~g} \mathrm{FW}$, respectinvely). Interestingly, fresh young fruits of Ma-mao (Antidesma velutinosum Blume) had a very low amount of formic acid (Not detectable, ND), but the amount of formic acid increased during the ripening process $(115 \pm 15 \mathrm{mg} / 100 \mathrm{~g} \mathrm{FW})$. For other parts of consumed plants, most contained low or no amounts of formic acid.

\subsubsection{Acetic Acid}

While there are no reports of acetic acid in plants, this study found very high acetic acid content in fresh young and fresh ripe fruits of Ma-mao (Antidesma velutinosum Blume) (1976 \pm 155 and $1354 \pm 192 \mathrm{mg} / 100 \mathrm{~g}$ FW, respectively). Fresh young leaves of Tew-daeng (Cratoxylum formosum subsp. Pruniflorum [Kurz] Gogel.) also had a high acetic acid level (1508 $\pm 325 \mathrm{mg} / 100 \mathrm{~g}$ FW). Fresh and blanched flower of Pak-wan-pa (Melientha suavis Pierre) contained high acetic acid (859 \pm 73 and $572 \pm 156 \mathrm{mg} / 100 \mathrm{~g} \mathrm{FW}$, respectively), whereas young leaves and fruit contained very low acetic acid $(22 \pm 6 \mathrm{mg} / 100 \mathrm{~g}$ FW and not detectable, respectively). Moreover, the acetic acid content of fresh young leaves of Som-mong (Garcinia cowa Roxb.ex DC.) was three times higher than that of boiled young leaves ( $470 \pm 73 \mathrm{mg}$ compared to $153 \pm 4 \mathrm{mg} / 100 \mathrm{~g} \mathrm{FW}$ ).

\subsection{Ascorbic Acid}

The highest ascorbic acid content was found in fruits of Ma-karm-pom (Phyllanthus emblica L.) (648 $\pm 189 \mathrm{mg} / 100 \mathrm{~g} \mathrm{FW})$, which agrees well with a previous study [29] (575 $\pm 452 \mathrm{mg} / 100 \mathrm{~g} \mathrm{FW})$. A high level of ascorbic acid was found in leaves of Som-mong (Garcinia cowa Roxb.ex DC.), both fresh and blanched ( $340 \pm 59$ and $356 \pm 78 \mathrm{mg} / 100 \mathrm{~g}$ FW respectively), and leaves of fresh Som-lom (Aganonerion polymorphum Pierre ex Spire) $(329 \pm 58 \mathrm{mg} / 100 \mathrm{~g} \mathrm{FW})$. Ascorbic acid in fresh fruits of Ma-kok-pa (Spondias pinnata (L.f.) Kurz) and Ma-mao (Antidesma velutinosum Blume) were $37 \pm 10$ and $2 \pm 1 \mathrm{mg} / 100 \mathrm{~g} \mathrm{FW}$, respectively, which were similar to the results of a previous study [29]. Young leaves in the family of Guttiferae, which has a strong sour taste, such as Tew-deang (Cratoxylum formosum subsp. Pruniflorum [Kurz] Gogel, Tew-kaw (Cratoxylum formosum [Jack] Dyer), and Tew-mon (Cratoxylum cochinchinense [Lour.] Blume), also contained high amounts of ascorbic acid (142 $\pm 35,136 \pm 34$, and $102 \pm 36 \mathrm{mg} / 100 \mathrm{~g} \mathrm{FW}$, respectively).

\subsection{Total Acidity and $\mathrm{pH}$}

High total acidity and low $\mathrm{pH}$ (a measure of the power of an acid in sample) measurements are used in sour taste indicators. Som-mong (Garcinia cowa Roxb.ex DC.), both blanched and fresh leaves, provided the highest total acidity content $(16.27 \% \pm 0.03 \%$ and $16.07 \% \pm 0.10 \% \mathrm{FW}$, respectively) but they had very low pH (3.81 \pm 0.10 and $3.80 \pm 0.12$, respectively). Fruits of Ma-mao (Antidesma velutinosum Blume), Ma-karm-pom (Phyllanthus emblica L.), and Ma-kok-pa (Spondias pinnata (L.f.) Kurz) had high total acidity $(13.74 \% \pm$ $0.30 \%, 13.45 \% \pm 0.14 \%$ and $13.16 \% \pm 0.30 \% \mathrm{FW}$, respectively); whereas they had 
low pH $(3.75 \pm 0.33,3.48 \pm 0.24$ and $3.24 \pm 0.07$, respectively). Leaves of Tew-deang (Cratoxylum formosum subsp. Pruniflorum [Kurz] Gogel) and fresh flowers of Kra-don (Careya sphaerica Roxb) also contained moderate total acidity $(6.09 \% \pm 0.71 \%$ and $4.29 \% \pm 0.31 \% \mathrm{FW}$, respectively) and slightly acid with a low $\mathrm{pH}(5.50 \pm 0.13$ and $5.49 \pm 0.30)$. The other plant parts had total acidity less than $4.0 \%$ and $\mathrm{pH}$ more than 5.3 .

\subsection{Sum of Organic Acids Contribution to Energy}

Organic acids have been used as a component in calculating total energy apart from protein, fat, and carbohydrate, by providing $3 \mathrm{kcal} / \mathrm{g}$ [15]. Only some fermented foods and foods containing high amounts of total organic acids could affect the energy levels of those foods. Limited information exists in the different food composition databases around the world concerning energy from organic acids as part of total energy. From the studied plants, seven samples out of forty plants, namely fruits of Ma-karm-pom (Phyllanthus emblica L.), and Ma-kok-pa (Spondias pinnata (L.f.) Kurz), fresh young leaves of Tew-deang (Cratoxylum formosum subsp. Pruniflorum [Kurz] Gogel), fresh young fruits of Ma-mao (Antidesma velutinosum Blume), fresh flower of Kra-don (Careya sphaerica Roxb), fresh ripe fruits of Ma-mao (Antidesma velutinosum Blume), and fresh young leaves of Tew-kaw (Cratoxylum formosum [Jack] Dyer) had high energy contributions in descending order of $36,22,16,16,13,10$, and $10 \mathrm{kcal} / 100 \mathrm{~g} \mathrm{FW}$, respectively. Organic acids in other parts of the above plants, and other plants, contributed energy of less than $10 \mathrm{kcal} / 100 \mathrm{~g}$ fresh weight. Consequently, energy from the sum of organic acids could be included for only some plants, especially for those with higher amounts.

\subsection{Correlation between Organic Acid and Other Parameters}

According to traditional belief, sour-tasting food is probably high in vitamin C or ascorbic acid. However, this belief may not always be true, because organic acids in a plant may also play an important role in causing a sour taste. Pearson's coefficient correlations $(r)$ were used here due to the common and complex interactions between all parameters related with the sour taste (Table 7). In general, it is well-known that lower $\mathrm{pH}$ and high total acidity could indicate a sour taste in food. Results from this study demonstrated that the sum of organic acids in the studied plants presented significant and inverse correlations with $\mathrm{pH}(r=$ $-0.680)$ and the total acidity positive correlations $(r=0.672)$ but were not significantly correlated with ascorbic acid $(r=0.536)$. For all individual organic acids, only oxalic acid had a significantly positive correlation with ascorbic acid $(r=0.670)$, whereas a study by Suarez et al. [30] reported a negative correlation $(r=-0.156)$. The $\mathrm{pH}$ is strongly inversely correlated with total acidity $(r=-0.913)$ which agrees with the trend in the Suarez et al. [30] study in different cultivars of tomatoes $(r=-0.384)$. The $\mathrm{pH}$ also had a notable negative correlation with the sum of organic, citric, and formic acids by order of $r=-0.680,-0.660$, and -0.595 , respectively, but was not correlated with ascorbic acid $(r=-0.494)$. Total 
Table 7. Pearson's correlation of all parameters for all studied samples.

\begin{tabular}{|c|c|c|c|c|c|c|c|c|c|}
\hline Parameters & Oxalic & Citric & Malic & Succinic & Formic & Acetic & Ascorbic & $\mathrm{pH}$ & Total acidity \\
\hline Sum organic acids & $0.814^{\mathrm{a}, \mathrm{b}}$ & $0.881^{\mathrm{b}}$ & $0.673^{\mathrm{b}}$ & 0.288 & $0.866^{\mathrm{b}}$ & $0.816^{\mathrm{b}}$ & 0.536 & $-0.680^{\mathrm{b}}$ & $0.672^{\mathrm{b}}$ \\
\hline Oxalic & & $0.660^{\mathrm{b}}$ & 0.323 & -0.122 & $0.930^{\mathrm{b}}$ & $0.506^{\mathrm{b}}$ & $0.670^{\mathrm{b}}$ & $-0.519^{b}$ & 0.485 \\
\hline Citric & & & -0.144 & -0.340 & 0.171 & $0.907^{\mathrm{b}}$ & -0.226 & $-0.660^{\mathrm{b}}$ & $0.648^{\mathrm{b}}$ \\
\hline Malic & & & & 0.397 & 0.514 & 0.129 & 0.030 & -0.126 & 0.242 \\
\hline Succinic & & & & & 0.370 & 0.365 & -0.024 & -0.262 & 0.178 \\
\hline Formic & & & & & & 0.380 & 0.006 & $-0.595^{\mathrm{b}}$ & $0.539^{\mathrm{b}}$ \\
\hline Acetic & & & & & & & -0.078 & -0.501 & 0.515 \\
\hline Ascorbic & & & & & & & & -0.494 & $0.570^{\mathrm{b}}$ \\
\hline $\mathrm{pH}$ & & & & & & & & & $-0.913^{\mathrm{b}}$ \\
\hline
\end{tabular}

${ }^{\mathrm{a}}$ Pearson's coefficient correlation; ${ }^{\mathrm{b}}$ Correlation is significant at the 0.01 level (2-tailed).

acidity presented a significantly positive correlation with the sum of organic, citric, formic, and ascorbic acids ( $r=0.672,0.648,0.539$, and 0.570 , respectively). In terms of the sour taste in plants, as indicated by low $\mathrm{pH}$ and high total acidity, this finding suggests that this taste could come from a sum of organic, citric, and formic acids, but not from ascorbic acid.

\section{Conclusion}

Forty samples from 29 indigenous plants were collected three times from two conservation areas in Thailand. They were analyzed for organic acids (citric, malic, succinic, formic, acetic, and oxalic acids), ascorbic acid, $\mathrm{pH}$, and total acidity, and evaluated in terms of the relationship of sour taste, using low $\mathrm{pH}$ and high total acidity, amongst other parameters. Young leaves in the family of Guttiferae, which has a strong sour taste, such as Tew-mon (Cratoxylum cochinchinense [Lour.] Blume), Tew-kaw (Cratoxylum formosum [Jack] Dyer), and Tew-deang (Cratoxylum formosum subsp. Pruniflorum [Kurz] Gogel) contained a high sum of organic acid, especially succinic, high ascorbic acid, and low $\mathrm{pH}$. On the other hand, fresh fruits of Ma-kok-pa (Spondias pinnata [L.f.] Kurz), and Ma-mao (Antidesma velutinosum Blume), which has a strong sour taste, contained high amounts of sum organic acids, especially oxalic acid, total acidity, and low $\mathrm{pH}$, but low ascorbic acid. This correlation of sour taste, indicated by low $\mathrm{pH}$ and high total acidity, indicates that the sour taste of plants could mainly come from the sum of organic, citric, and formic acids, but not only from ascorbic acid. This study is the first to provide database information for organic acids in Thai plants and especially in terms of the correlation of organic acid to the sour taste. This study also showed that the energy from organic acid of plants minimally contributes to recommended energy.

\section{Acknowledgements}

We are grateful to the Plant Genetic Conservation Project under the Royal Initi- 
ative of Her Royal Highness Princess Maha Chakri Sirindhorn (RSPG), Thailand, for their kind collaboration and in facilitating access to the conservation areas, as well as to Assistant Professor Kasem Kulpadit and local people teams to collect all studied samples. We also thank the Mahidol University and the National Research Council of Thailand (NRCT) for providing financial support. We would like to express sincere thanks to Institute of Nutrition, Mahidol University for providing support for all facilities, as well as to Assistant Professor Sitima Jittinandana for $\mathrm{pH}$ and total acidity determinations, and to Mr. Attig A George for language manuscript editing.

\section{Conflicts of Interest}

The authors declare no conflicts of interest regarding the publication of this paper.

\section{References}

[1] Robinson, T. (1983) The Organic Constituents of Higher Plants: Their Chemistry and Interrelationships. Cordus Press, North Amherst, MA.

[2] Dashek, W.V. and Micales, A.M. (1997) Methods in Plant Biochemistry and Molecular Biology. CRC Press, Boca Raton, FL.

[3] Palmer, J.K. and List, D.M. (1973) Determination of Organic Acids in Foods by Liquid Chromatography. Food Chemistry, 21, 903-906. https://doi.org/10.1021/jf60189a019

[4] Silva, G.H., Chase, R.W., Hammercshmidt, R. and Cash, J.N. (1991) After-Cooking Darkening of Spartan Pearl Potatoes as Influenced by Location, Phenolic Acids, and Citric Acid. Journal of Agricultural and Food Chemistry, 39, 871-873. https://doi.org/10.1021/jf00005a011

[5] Charoenkiatkul, S., Judprasong, K., Sukprasansap, M., Thiyajai, P. and Kettawan, A. (2012) Survey and Database Development of Nutrients, Bioactive Compounds and Health Benefit of Local Foods at Conserve Area of Plant Genetic Conservation Project under the Royal Initiative of Her Royal Highness Princess Maha Chakri Sirindhorn. Kanchanaburi Province, Report.

[6] Penniston, K.L., Nakada, S.Y., Holmes, R.P. and Assimos, D.G. (2009) Quantitative Assessment of Citric Acid in Lemon Juice, Lime Juice, and Commercially-Available Fruit Juice Products. Journal of Endourology, 22, 567-570. https://doi.org/10.1089/end.2007.0304

[7] Penniston, K. (2012) Citric Acid and Kidney Stones. UW Health Clinical Nutrition. https://www.uwhealth.org/files/uwhealth/docs/pdf/kidney_citric_acid.pdf

[8] Seltzer, M.A. Low, R.K., McDonald, M. and Stoller, M.L. (1996) Dietary Manipulation with Lemonade to Treat Hypocitraturic Calcium Nephrolithiasis. Journal of Urology, 156, 907-909. https://doi.org/10.1016/S0022-5347(01)65659-3

[9] Kang, D.E, Sur, R.L., Haleblian, G.E., Fitzsimons, N.J., Borawski, K.M. and Preminger, G.M. (2007) Long-Term Lemonade Based Dietary Manipulation in Patients with Hypocitraturic Nephrolithiasis. The Journal of Urology, 177, 1358-1362. https://doi.org/10.1016/j.juro.2006.11.058

[10] Gómez Moreno, G., Guardia, J., Aguilar Salvatierra, A., Cabrera Ayala, M., Maté Sánchez de Val, J.E. and Calvo Guirado, J.L. (2013) Effectiveness of Malic Acid 1\% in Patients with Xerostomia Induced by Antihypertensive Drugs. Journal Section: 
Odontostomatology for the Disabled or Special Patients, 18, e49-e55. https://doi.org/10.4317/medoral.18206

[11] Sakamoto, M.T.K., Yasui, H. and Tokunaga, K. (1998) Cardioprotective Effect of Succinate against Ischemia/Reperfusion Injury. Surgery Today, 28, 522-528. https://doi.org/10.1007/s005950050177

[12] William, S. (2010) The Role of Oxalates in Autism and Chronic Disorders. https://www.westonaprice.org/health-topics/vegetarianism-and-plant-foods/the-rol e-of-oxalates-in-autism-and-chronic-disorders/

[13] Crampton, L. (2011) Formic Acid Dangers and Uses in Nature and in Humans. http://hubpages.com/hub/Formic-Acid-Dangers-and-Uses-in-Nature-and-in-Hum ans

[14] Sha, S., Li, J., Wu, J. and Zhang, S. (2011) Characteristics of Organic Acids in the Fruit of Different Pear Species. African Journal of Agricultural Research, 6, 2403-2410.

[15] Greenfield, H. and Southgate, D.A.T. (2003) Food Composition Data: Production, Management and Use. Food and Agriculture Organization of the United Nations, Rome, Italy.

[16] George, W.L. (2016) Official Methods of Analysis of AOAC International. 20th Edition, Method, 927.

[17] AOAC International (2016) Guidelines for Standard Method Performance Requirements AOAC Official Methods of Analysis. Appendix F, 1-18. http://www.eoma.aoac.org/app_f.pdf

[18] Savage, G.P., Vanhanen, L. and Mason, S.M. (2002) Effect of Cooking on the Soluble and Insoluble Oxalate Content of Some New Zealand Foods. Journal of Food Composition and Analysis, 13, 201-206. https://doi.org/10.1006/jfca.2000.0879

[19] Judprasong, K., Charoenkiatkul, S., Sungpuag, P., Vasanachitt, K. and Nakjamanong, Y. (2006) Total and Soluble Oxalate Contents in Thai Vegetables, Cereal Grains and Legume Seeds and Their Changes after Cooking. Journal of Food Composition and Analysis, 19, 340-347. https://doi.org/10.1016/j.jfca.2005.04.002

[20] Sanchez-Mata, M. C., Camara-Hurtado, M., Diez-Marques, C., \& Torija-Isasa, E. (2000) Comparison of High-Performance Liquid Chromatography and Spectrofluorimetry for Vitamin C Analysis of Green Beans (Phaseolus vulgaris L.) European Food Research and Technology, 210, 220-225. https://doi.org/10.1007/PL00005516

[21] Virginia, P., Verma, S. and Ajit, P. (2012) Effect of Cooking and Processing Methods on Oxalate Content of Green Leafy Vegetables and Pulses. Asian Journal of Food and Agro-Industry, 5, 311-314.

[22] Hong Nguyen, H.V. and Savage, G.P. (2013) Oxalate Content of New Zealand Grown and Imported Fruits. Journal of Food Composition and Analysis, 31, 180-184. https://doi.org/10.1016/j.jfca.2013.06.001

[23] Yoshikawa, T., Nakagawa, K., Kobayashi, T., Tokieda, S. and Nagai, K. (1988) Studies on High Quality Production and Shipment of Spinach 1. Effects of Varieties and Growth Stage on Oxalic Acid Content. Kinki Chugoku Agricultural Research, 75, 71-76. (In Japanese)

[24] Soumya, S.L. and Nair, B.R. (2014) Changes in the Biochemical Profile of Fruits of Two Species of Averrhoa during Development. International Journal of Pharmacy and Pharmaceutical Sciences, 6, 572-577.

[25] Theron, M.M. and Lues, J.F.R. (2011) Organic Acids and Food Preservation. CRC Press, Boca Raton, FL, 340 p. https://doi.org/10.1201/9781420078435 
[26] Rasmussen, G.K. and Smith, P.F. (1961) Effects of Calcium, Potassium, and Magnesium on Oxalic, Malic, and Citric Acid Content of Valencia Orange Leaf Tissue. Plant Physiology, 36, 99-101. https://doi.org/10.1104/pp.36.1.99

[27] DeKock, P.C. and Morrison, R.I. (1958) The Metabolism of Chlorotic Leaves. 2. Organic Acids. Biochemical Journal, 70, 272-277. https://doi.org/10.1042/bj0700272

[28] Engelhardt, U.H. and Maier, H.G. (1985) Acids in Coffee. XI. The Proportion of Individual Acids in the Total Titratable Acid. Zeitschrift fur Lebensmittel-Untersuchung und Forschung, 181, 20-23. https://doi.org/10.1007/BF02425579

[29] Judprasong, K., Charoenkiatkul, S., Thiyajai, P. and Sukprasansap, M. (2013) Nutrients and Bioactive Compounds of Thai Indigenous Fruits. Food Chemistry, 140, 507-512. https://doi.org/10.1016/j.foodchem.2013.01.057

[30] Suarez, M.H., Rodriguez, E.R. and Romero, C.D. (2008) Analysis of Organic Acid Content in Cultivars of Tomato Harvested in Tenerife. European Food Research and Technology, 226, 423-435. https://doi.org/10.1007/s00217-006-0553-0 